turers depower air bags by $30 \% .^{1}$ Also, it is now possible for certain drivers in the United States to have a switch installed that would deactivate the air bags.

\section{References}

1. National Highway Safety Transportation Administration: Actions to reduce the adverse effects of air bags: FMVSS No. 208. Available on the World Wide Web at http://www.nhtsa.dot.gov, 1997

2. Swanson-Biearman B, Mrvos R, Dean BS, Krenzelok EP: Air bags: Lifesaving with toxic potential? Am J Emerg Med 1:38, 1993

3. Augenstein JS, Digges KH, Lobardo LV, et al: Uccult abdominal injuries to airbag-protected crash victims: A challenge to trauma systems. J Trauma 38:502, 1995

4. Antosia RE, Partridge RA, Virk AS: Air bag safety. Ann Emerg Med 25:794, 1995

5. Garcia R: Air bag implicated in temporomandibular joint injury. J Craniomandib Prac 12:125, 1994

6. Nitzan D, Dolwick MF, Martinez GA: Temporomandibular joint arthrocentesis: A simplified treatment for severe, limited mouth opening. J Oral Maxillofac Surg 49:1163, 1991

7. Smally AJ, Binzer A, Dolin S, et al: Alkaline chemical keratitis: Eye injury from airbags. Ann Emerg Med 21:1400, 1992

8. Huelke DF, Moore JL, Ostrom M: Air bag injuries and occupant protection. J Trauma 33:894, 1992
9. Huelke DF, Moore JL, Compton TW, et al: Upper extremity injuries related to airbag deployments. J Trauma 38:482, 1995

10. Gault JA, Vichnin MC, Jaeger EA, et al: Ocular injuries associated with eyeglass wear and airbag inflation. J Trauma 38:494, 1995

11. Zador PL, Ciccone MA: Automobile driver fatalities in frontal impacts: Air bags comparcd with manual belts. Am J Public Health 83:661, 1993

12. Blacksin MF: Patterns of fracture after air bag deployment. $J$ Trauma 35:840, 1993

13. Kuhn F, Morris R, Witherspoon CD, et al: Air bag: Friend or foe? Arch Ophthmol 111:1333, 1993

14. Hendey GW, Votey SR: Injuries in restrained motor vehicle accident victims. Ann Emerg Med 24:77, 1994

15. Newman L: Driver's airbags and facial injuries. (letter) Brit J Oramaxillofac Surg 34:480, 1996

16. Scott IU, John GR, Stark WJ: Airbag-associated ocular injury and periorbital fractures. Arch Ophthalmol 111:25, 1993

17. Rozner L: Air bag-bruised face. Plast Reconstr Surg 97:1517, 1996 (letter)

18. Cacciatori M, Bell R, Habib N: Blow-out fracture of the orbit associated with inflation of an airbag: A case report. $\mathrm{Br} \mathrm{J}$ Oralmaxillofac Surg 35:241, 1997

19. Hallock G: Mechanisms of burn injury secondary to airbag deployment. Ann Plast Surg 39:111, 1997

20. Lancaster GI, DeFrance J, Borruso J: Air-bag-associated rupture of the right atrium. N Engl J Med 4:358, 1993 (letter)

\title{
Retropharyngeal Lipoma Causing Sleep Apnea Syndrome
}

\author{
Stefano Di Girolamo, MD, ${ }^{*}$ Luca Marinelli, MD, $\dagger$ \\ Alessandra Galli, MD, $\neq$ and Fabrizio Ottaviani, $M D \mathfrak{I}$
}

Lipomas are benign, slow-growing, mesenchymal neoplasms composed of mature fat cells. Although very common, their location in the head and neck region is relatively rare $(13 \%) .{ }^{1}$ Head and neck lipomas are more commonly seen in the subcutaneous tissues of the neck, whereas they have seldom been reported in the oral cavity, larynx, and pharynx. Lipomas of the retropharyngeal space are seldom reported; no more than 20 cases have been described in the literaturc. ${ }^{2,3}$

Received from the Institute of Otorhinolaryngology, Catholic University of the Sacred Heart, Rome, Italy.

*Fellow.

†Resident.

†Fellow.

§Associate Professor.

Address correspondence and reprint requests to Dr Di Girolamo: Institute of Otorhinolaryngology, Catholic Universily of the Sacred Heart, Largo A. Gemelli, 8, 00168 Roma, Italy.

- 1998 American Association of Oral and Maxillofacial Surgoons 0278-2391/98/5608-0018\$3.00/0
Because of the slow growth rate, symptoms are late, and the mass can reach a large size before causing airway obstruction. A case of retropharyngeal lipoma causing obstructive sleep apnea is described.

\section{Report of Case}

A 56-year-old man presented with a 2-year history of upper airway obstruction, snoring, and frequent episodes of sleep apnea. Anterior rhinoscopy showed normal mucosa, straight nasal septum, and normal turbinates. Examination of the oropharyux showed a soft, nonpulsating, submucosal mass, covered by normal mucosa, bulging from the posterior pharyngeal wall, mainly on the left side. The tumor extended from the inferior part of nasopharynx as far as the margin of the epiglottis.

$\Lambda$ computed tomography (CT) scan showed a fat-density mass located between the muscular plane of the pharyngeal constrictors and the prevertebral plane (Fig 1). Fine needle aspiration (FNA) excluded malignancy. The mass was diagnosed as a lipoma and removed by transoral pharyngotomy; tracheotomy was not necessary. A nasogastric tube was maintained during the first 3 days after surgery.

Macroscopically, the multilobulated tumor was yellowish with a shiny surface, and it appeared well encapsulated. It measured $9.5 \times 6 \times 4 \mathrm{~cm}$. 


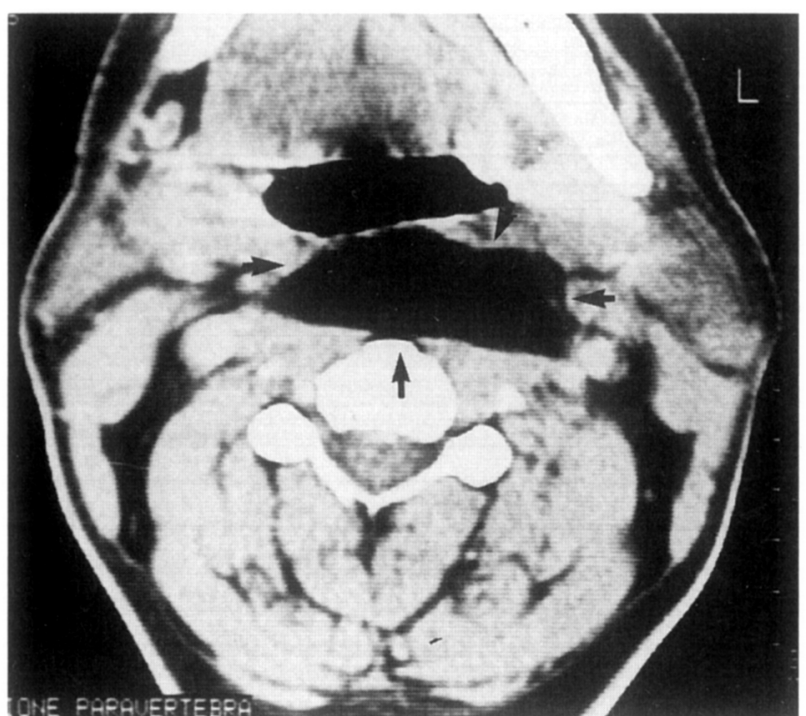

FIGURE 1. CT scan showed a fat-density mass (arrow) located between the muscular plane of pharyngeal constrictors and the prevertebral plane, mostly on the left side.

Microscopically, the mass was a typical lipoma. On follow-up, the patient reported that his snoring had significantly reduced and sleep apnea episodes had disappeared as demonstrated by polysomnography. Daytime somnolence had also reduced significantly.

\section{Discussion}

Lipomas are not commonly found in the upper aerodigestive tract. ${ }^{4,5}$ However, different reports have described lesions in the tongue, floor of the mouth, and lips, and, less frequently, in the peritonsillar space, hypopharyngeal wall, and aryepiglottic fold. ${ }^{6}$ Presence in the retropharyngeal space is rare, and the mass has been submucosal in all cases reported in literature. To our knowledge, only one other case with a retromuscular location has been reported. ${ }^{7}$ Lipomas of the retropharyngeal area will usually grow to a large size before they are discovered, and the initial symptom is often related to the airway, that is, nasal obstruction or snoring, depending on the location and size of the mass. ${ }^{1} \mathrm{~A}$ case of retropharyngeal lipoma also causing obstructive sleep apnea has recently been reported. ${ }^{8}$

Obstructive sleep apnea syndrome is diagnosed when more than five desaturations per hour $\left(\mathrm{PO}_{2}<80 \%\right)$ can be recorded by polysomnography, while dangerous OSAS is diagnosed when more than 20 desaturations per hour occur. The prevalence among adults is higher in men (9\%) than in women (4\%). ${ }^{9}$ Obstruction can have different causes, including soft palate and base of tongue hypertrophy, nasal obstruction, and other morphologic conditions causing the narrowing of the superior airway tract.

Neoplasms of the pharynx are not frequently re- ported as a cause of OSA. In a series of 336 OSA patients, only three were secondary to pharyngeal neoplasms, all of which were benign. ${ }^{10}$ Parapharyngeal masses, however, usually present with different symptoms, such as dysphagia or pain, ${ }^{11}$ although in one case of carotid body paraganglioma reported by Meterski ct al, ${ }^{12}$ the prescnting symptom was OSA.

Although magnetic resonance imaging can provide more accurate imaging, ${ }^{13,14}$ artifacts may appear due to breathing movements. A CT scan can also provide adequate information with regard to the composition and extension of the mass. A homogeneous, lowattenuation mass with no clearly defined capsule, and with a sharp demarcation from the surrounding tissue, is highly suggestive of a lipoma. More heterogeneity or density on the CT scan may indicate a liposarcoma.

The benign nature of the tumor, confirmed by FNA, and the detailed radiologic description, enabled us to use a transoral surgical approach, which is much less invasive than cervicotomy, but more challenging because of the narrow surgical area.

The resolution of sleep apnea symptoms after the surgical procedure confirmed the obstructive nature of the lesion. This suggests that any patient presenting with sleep apnea should undergo a careful evaluation of the upper aerodigestive tract.

\section{References}

1. Messeguer H, Ortega G, Galvez M: Pharyngeal lipoma. An ORL lbero Am 3:247, 1994

2. Ferrari G, Ferri T, Bolla I, et al: A case of lipoma in pharyngeal site. Acta Biomed Ateneo Parmense 55:315, 1984

3. Carbonell Sanchis R, Pérez Climent F, Giménez Vaillo F, et al Retropharyngeal lipoma. An Otorrinolaringol Ibero Am 23:389 1996

4. Masson I, Wilske J, Kindblom LG: Lipoma of the hypopharynx: A case report and a review of the literature. J Laryngol Otol 92:1037-1043, 1978

5. Fu Y-S, Perzin KH: Non-epitelial tumors of the nasal cavity, paranasal sinuses and nasopharynx: A clinicopathologic study. VIII. Adipose tissue tumors (lipoma and liposarcoma). Cancer 40:1314, 1977

6. Batsakis JG: Tumors of the Head and Neck (ed 2). Baltimore MD, Williams \& Wilkins, 1979, pp 360-361

7. Pitts D, Hilsinger R: Retronasopharyngeal lipomas: A case report. Otolaryngol Head Neck Surg 100:248-251, 1989

8. Aland GW Jr: Rctropharyngcal lipoma causing symptoms of obstructive sleep apnea. Otolaryngol Head Neck Surg 114:628, 1996

9. Young $T$, Palta $M$, Dempsey $J$, et al: The occurrence of sleep-disordered breathing among middle-aged adults. $N$ Engl $\mathrm{J}$ Med 328:1230, 1993

10. Mayer-Brix J, Muller-Marschhausen $\mathrm{U}$, Becker $\mathrm{H}$, et al: Wie häufig sind pathologische HNO-Befunde bei Patienten mit obstruktivem Schlaf-Apnoe-Syndrome? HNO 37:511, 1989.

11. Veitch D, Rogers M, Blanshard J: Parapharyngeal mass presenting with sleep apnea. J Laryngol Otol 103:961, 1989

12. Metersky M, Castriotta $R$, Elnaggar A: Obstructive sleep apnea due to a carotid body paraganglioma. Sleep 18:53, 1995

13. Cottrell D, Norris L, Duke H: Orofacial lipomas diagnosed by CT and MRI. J Am Dent Assoc 124:110, 1993

14. Yamashita $K$, Fuji $T$, Nakai T, et al: Extradural spinal angiolipoma: Report of a case studied with MRI. Surg Neurol 39:49, 1993 